\title{
ANALISIS KREDIT BERMASALAH DILIHAT DARI STANDAR NON PERFORMING LOAN (NPL) PADA PT. BANK PERKREDITAN RAKYAT (BPR) PRIMA MULIA ANUGRAH CABANG PADANG
}

\author{
ARIF FIRMANSYAH, JHON FERNOS \\ Akademi Keuangan dan Perbankan "Pembangunan" Padang \\ Jhonfernos@akbpstie.ac.id
}

\begin{abstract}
This research was aimed to know: (1) the cause of non performing loan at PT. BPR Prima Mulia Anugrah Padang branch in 2015-2017, (2) the impact of non performing loan to the profit of company in 2015-2017, (3) the effort which is done to overcome the non performing loan at PT. BPR Prima Mulia Anugrah Padang branch in 2015-2017. The data were collected by using interview and documentation. The data were analyzed using case study analysis with quantitative approach. The result of the study showed that (1) non performing loan to four accasioned factor, that is: the lack of officers accuracy in loan analysis, the bad faith of officers of PT BPR Prima Mulia Anugrah Padang branch, the lack of loan suvervision system, and economic downturn. (2) the impact of non performing loan toward the Bank were profit decreases, disruption of cash turnover, the reduce of the bank healty level, the reduce of bank capital, and decline in public confidence. (3) the effort which was done to overcome the non performing loan at PT. BPR Prima Mulia Anugrah Padang branch were restructuring, rescheduling, foreclosure bail, and loan deletion (account receivable deletion).
\end{abstract}

Keywords: non performing loan.

\section{PENDAHULUAN}

Bank menurut undang-undang No. 10 Tahun 1998, bank adalah badan usaha yang menghimpun dana dari masyarakat dalam bentuk simpanan dan menyalurkannya kepada masyarakat dalam bentuk kredit atau bentuk lainnya dalam rangka meningkatkan taraf hidup rakyat banyak.

Bank memiliki peranan yang sangat penting dalam mendorong pertumbuhan ekonomi suatu negara. Semua sektor usaha baik sektor industri, perdagangan, pertanian, perkebunan, jasa dan yang bersifat non keuangan lainnya sangat membutuhkan bank sebagai mitra dalam mengembangkan usahanya.

Salah satu peranan bank menurut (Sari, 2013) adalah Pembangunan, dan pertumbuhan ekonomi tidak terlepas dari peran sektor perbankan. Bank 
Umum memiliki peranan penting dalam menggerakkan roda perekonomian nasional, karena lebih dari 95\% Dana Pihak Ketiga berada pada Bank Umum. Penyaluran kredit merupakan salah satu aktivitas bank umum yang paling utama dalam menghasilkan keuntungan. Namun penyaluran kredit belum optimal dilihat dari tingkat LDR yang berada dibawah harapan Bank Indonesia. Data yang digunakan merupakan data sekunder dari Bank Indonesia. Teknik analisis yang digunakan adalah regresi linier berganda dengan me. Dalam memberikan kredit tersebut, hampir setiap bank mengalami kredit bermasalah atau dengan kata lain nasabah tidak mampu lagi untuk melunasi kreditnya dan hal ini menimbulkan kerugian bagi pihak bank, terjadinya kredit bermasalah dapat diakibatkan oleh beberapa faktor diantaranya, nasabah sengaja tidak mau membayar kreditnya padahal mampu, atau hal tersebut dapat juga diakibatkan karena nasabah tidak sengaja misalnya, akibat terjadinya bencana alam. Oleh karena itu, setiap bank harus mengendalikan kreditnya dengan baik dan melakukan penanggulangan atau penyelesaian terhadap kredit yang digolongkan bermasalah.

(Kurniawan \& Kriestanto, 2016) Dalam dunia perbankan, pemberian kredit kepada nasabah adalah kegiatan rutin yang mempunyai resiko tinggi. Dalam pelaksanaannya, kredit yang bermasalah (kredit macet) sering terjadi akibat analisis kredit yang tidak hati-hati atau kurang cermat dalam proses pemberian kredit, maupun dari karakter nasabah yang tidak baik. Untuk mencegah terjadinya kredit macet, diperlukan adanya peramalan akurat yang salah satunya menggunakan teknologi di bidang data mining. Dengan menggunakan teknologi di bidang data mining yang mengoptimasi proses pencarian informasi prediksi dalam basis data yang besar, serta menemukan pola-pola yang tidak diketahui sebelumnya. Naïve Bayes memprediksi probabilitas di masa depan berdasarkan pengalaman di masa sebelumnya dengan mempelajari korelasi hipotesis yang merupakan label kelas yang menjadi target pemetaan dalam klasifikasi dan evidence yang merupakan fitur-fitur yang menjadi masukan dalam model klasifikasi. Pengolahan data berbasis data mining tersebut diharapkan dapat digunakan sebagai alat bantu dalam memprediksikan kelayakan kredit yang memperkirakan layak atau tidaknya pemohon atau nasabah untuk diberikan kredit. Penanggulangan kredit adalah suatu usaha atau tindakan penyelesaian kredit yang dilakukan oleh bank terhadap kredit yang digolongkan sebagai kredit bermasalah. Penanggulangan kredit merupakan tindakan terakhir yang dilakukan bank dalam menyelesaikan atau mengatasi kredit bermasalah setelah upaya pembinaan kredit dilakukan.

Bank Perkreditan Rakyat adalah lembaga keuangan bank yang menerima simpanan hanya dalam bentuk deposito berjangka,tabungan atau bentuk lainnya yang dipersamakan dan menyalurkan dana sebagai usaha Bank Perkreditan Rakyat.

Bank perkreditan Rakyat Prima Mulia Anugrah merupakan lembaga keuangan yang bergerak dalam usaha jasa perbankan yang memberikan pelayanan jasa pada nasabah dalam berbagai bentuk. Salah satu pelayanan yang diberikan oleh bank tersebut adalah dalam bentuk pemberian fasilitas 
kredit. Peningkatan pemberian kredit oleh bank dapat mengakibatkan laba yaitu berupa bunga atas pinjaman yang diberikan kepada nasabah dan juga akan menaikkan jumlah piutang pada bank tersebut. Dengan naiknya jumlah kredit akan diikuti pula oleh kemungkinan tidak tertagihnya kredit dan yang terjerat kedalam kredit bermasalah. Maka untuk menanggulangi atau menyelesaikan kredit bermasalah, harus diperlukan analisis penyelesaian kredit bermasalah yang tepat. Kredit bermasalah yang terjadi di PT. Bank Perkreditan Rakyat Prima Mulia Anugrah, selama 3 tahun terakhir yaitu dari tahun 2015 ,2016, dan 2017.

Berikut ini pemberian kredit yang terjadi pada PT. Bank Perkreditan Rakyat PMA Cabang Padang tiga tahun terakhir dapat dilihat pada tabel dibawah ini:

\section{Tabel 1.1}

Penyaluran kredit dan Jumlah Non Performing Loan (NPL) Pada tahun 2015-2017

\begin{tabular}{|c|c|c|}
\hline Tahun & Total Kredit & Jumlah NPL \\
\hline 2015 & Rp. 7.370 .507 & Rp. 899.776 \\
\hline 2016 & Rp. 7.238 .598 & Rp. 2.696.271 \\
\hline 2017 & Rp. 6.822.635 & Rp. 1.493 .815 \\
\hline Total & Rp. 21.431 .740 & Rp. 5.089.862 \\
\hline
\end{tabular}

Sumber : BPR PMA Cabang Padang,data diolah

Berdasarkan tabel 1.1 diatas terlihat perkembangan total Kredit dan jumlah Non Performing Loan (NPL) Pada PT. Bank Perkreditan Rakyat PMA Cabang Padang, tahun 2015 total kredit sebesar Rp. 7.370.507 dan jumlah NPL nya sebesar Rp. 899.776, tahun 2016 total kredit sebesar Rp. 7.238.598, jumlah NPL nya sebesar Rp. 2.696.271, selanjutnya pada tahun 2017 total kredit sebesar Rp. 6.822.635 dan jumlah NPL nya sebesar Rp. 1.493.815. Jadi total dari total kredit 2015-2017 sebesar Rp. 21.431 .740 dan total jumlah NPL sebesar Rp. 5.089.862.

Tujuan analisis ini adalah agar pihak bank dapat mengambil tindakan yang tepat dalam menyelesaikan kredit bermasalah yang ada. Oleh karena itu pentingnya analisis penyelesaian kredit bermasalah yang dilakukan oleh pihak bank dalam menanggulangi kredit yang digolongkan bermasalah, maka penulis tertarik melakukan penelitian yang dituangkan dalam bentuk tugas akhir yang berjudul: "Analisis Kredit Bermasalah Pada PT. Bank Perkreditan Rakyat Prima Mulia Anugrah Cabang Padang ”.

\section{METODE PENELITIAN}

\section{Metode Pengumpulan Data}

a. Riset lapangn (Field Research)

Yaitu peninjauan lansung keobjek penelitian yang dipilih untuk meneliti hasil data skunder. Adapun cara dengan mewawancarai lansung kepihakpihak yang berkepentingan dalam hal ini adalah PT. Bank Perkreditan Rakyat PMA Cabang padang atau instansi yang terkait. 
b. Riset Perpustakaan (Library Research)

Yaitu penyelidikan yang dilakukan melalui keperpustakaan atau pun buku-buku ilmiah dan tulisan-tulisan yang ada hubungan nya dengan pembahasan yang dilakukan. Penelitian perpustakaan ini bersifat teoritis, dimana dapat diapliklasikan dengan teori-teori yang berhubungan dengan penulisan ini.

\section{Metode Analisa Data}

Dalam menganalisa data, penulis menggunakan analisa data kuantitatif. Data kuantitatif merupakan data informasi yang berbentuk simbol angka atau bilangan, maka dari itu dengan metode ini penulis akan mencoba memberikan fakta-fakta atau kenyataan yang dialami PT. Bank Perkreditan Rakyat PMA Cabang

\section{Landasan Teori}

\section{Pengertian Bank Perkreditan Rakyat}

(Lubis, 2007) Bank Perkreditan Rakyat (BPR) merupakan suatu lembaga keuangan yang memiliki peranan yang cukup penting didalam mendorong perekonomian di Indonesia.

Bank Perkreditan Rakyat menerima simpanan hanya dalam bentuk deposito berjangka, tabungan dan bentuk lain yang dipersamakan dengan itu. Menurut pasal 13 undang-undang RI No. 10 tahun 1998 usaha Bank Perkreditan Rakyat (BPR) adalah:

a. Menghimpun dana dari masyarakat dalam bentuk simpanan deposito berjangka, tabungan atau bentuk lainnya yang dipersamakan dengan itu.

b. Memberikan kredit.

c. Menempatkan dana nya dalam bentuk sertifikat bank indonesia (SBI), deposito berjangka, sertifikat deposito dan atau tabungan pada bank lain.

\section{Pengertian Kredit}

(Siringoringo, 1988) Salah satu cara untuk memperoleh modal adalah dengan kredit. Kredit merupakan suatu fasilitas keuangan yang memungkinkan seseorang atau badan usaha untuk meminjam uang untuk membeli produk dan membayarnya kembali dalam jangka waktu yang ditentukan. UU No. 10 tahun 1998 menyebutkan bahwa kredit adalah penyediaan uang atau tagihan yang dapat dipersamakan dengan itu, berdasarkan persetujuan atau kesepakatan pinjam meminjam antara bank dengan pihak lain yang mewajibkan pihak peminjam untuk melunasi utangnya setelah jangka waktu tertentu dengan pemberian bunga. Jika seseorang menggunakan jasa kredit, maka ia akan dikenakan bunga tagihan.

\section{Jenis-jenis Kredit}

Secara umum jenis-jenis kredit yang ditawarkan meliputi:

a. Kredit investasi,

yaitu merupakan kredit yang diberikan kepada pengusaha yang melakukan investasi atau penanaman modal. Biasanya kredit jenis ini memiliki jangka waktu yang relatif panjang yaitu diatas 1(satu) tahun. Contoh kredit untuk membangun pabrik atau membeli peralatan pabrik seperti mesin-mesin. 
b. Kredit Modal Kerja,

merupakan kredit yang digunakan sebagai modal usaha. Biasanya kredit jenis ini berjangka waktu pendek yaitu tidak lebih dari 1(satu) tahun. Contoh untuk membeli bahan baku, membayar gaji karyawan dan modal kerja lainnya.

c. Kredit Perdagangan, merupakan kredit yang diberikan kepada para pedagang dalam rangka memperlancar atau memperluas atau memperbesar kegiatan perdagangannya. Contoh: untuk membeli barang dagangan yang diberikan kepada para suplier atau agen.

d. Kredit Produktif, merupakan kredit yang dapat berupa investasi, modal kerja atau perdagangan. Dalam arti kredit ini diberikan untuk diusahakan kembali sehingga pengembalian kredit diharapkan dari hasil usaha yang dibiayai.

e. Kredit Konsumtif, merupakan kredit yang digunakan untuk keperluan pribadi misalnya keperluan konsumsi, baik pangan, sandang maupun papan. Contoh: kredit perumahan, kredit kendaraan bermotor yang kesemuanya untuk dipakai sendiri.

f. Kredit Profesi, merupakan kredit yang diberikan kepada para kalangan profesional seperti dosen, dokter atau pengacara

\section{Analisa Kredit}

(Savitri, 2014) Persetujuan kredit ditentukan dari hasil analisis kredit. Kredit yang disetujui adalah kredit yang layak, telah sesuai dengan kebijakan dengan prosedur pemberian kredit, tidak menyimpang dari ketentuanketentuan limit kredit dan ketentuan pemerintah, telah dipertimbangkan mengenai keamanan kreditnya, dan diputus sesuai dengan kewenangan memutus kredit.

Hal yang perlu diperhatikan dalam menganalisis kredit yaitu nasabah harus memenuhi prinsip 5C, 7P, dan 3R yaitu sebagai berikut:

Penilaian berdasarkan asas $5 \mathrm{C}$ sebagai berikut:

\section{a. Character}

Adalah keadaan watak atau sifat dari nasabah baik dalam kehidupan pribadi maupun dalam lingkungan usaha. Kegunaan dari karakter ini adalah untuk mengetahui sampai sejauh mana iktikad atau kemauan nasabah untuk memenuhi kewajibannya sesuai dengan perjanjian yang telah ditetapkan. Sebagai alat untuk memperoleh gambaran tentang karakter dari calon nasabah tersebut, dapat ditempuh melalui upaya antara lain:

1) Meneliti riwayat hidup calon nasabah.

2) Meneliti reputasi calon nasabah dilingkungan usahanya.

3) Meminta informasi dari bank lain.

4) Mencari informasi kepada asosiasi usaha dimana calon nasabah berada. 
5) Mencari informasi apakah calon nasabah suka berjudi dan berfoyafoya.

b. Capital

Adalah jumlah dana atau modal sendiri yang dimiliki oleh calon nasabah. Semakin besar modal sendiri dalam perusahaan, tentu semakin tinggi kesungguhan calon nasabah dalam menjalankan usahanya dan bank akan merasa lebih yakin dalam memberikan kredit.

c. Capacity

Adalah kemampuan yang dimiliki calon nasabah dalam menjalankan usahanya guna memperoleh laba yang diharapkan. Apakah nasabah tersebut pernah mengalami permasalahan keuangan sebelumnya atau tidak, dimana prinsip ini menilai akan kemampuan membayar kredit nasabah terhadap bank.

\section{d. Collateral}

Prinsip ini perlu diperhatikan bagi para nasabah ketika mereka tidak dapat memenuhi kewajibannya dalam mengembalikan pinjaman dari pihak bank. Jika hal demikian terjadi, maka sesuai dengan ketentuan yang ada, pihak bank bisa saja menyita aset yang telah dijanjikan sebelumnya sebagai sebuah jaminan.

e. Condition of Economi

Prinsip ini dipengaruhi oleh faktor diluar dari pihak bank maupun nasabah. Kondisi perekonomian suatu daerah atau negara memang sangat berpengaruh kepada kedua belah pihak, dimana usaha yang dijalankan oleh nasabah sangat tergantung pada kondisi perekonomian baik mikro maupun makro, sedangkan pihak bank menghadapi permasalahan yang sama. Untuk memperlancar kerjasama dari kedua belah pihak, maka penting adanya untuk memperlancar komunikasi antara nasabah dengan bank.

Penilaian berdasarkan asas $7 \mathrm{P}$ dapat dilihat sebagai berikut:

a. Personality (kepribadian)

Yaitu menilai nasabah dari segi kepribadiannya atau tingkah lakunya sehari-hari. Personality juga mencakup sikap, emosi, tingkah laku dan tindakan nasabah dalam menghadapi suatu masalah.

b. Party

Yaitu mengklasifikasikan nasabah kedalam golongan-golongan tertentu berdasarkan modal, loyalitas serta karakternya sehingga nasabah dapat digolongkan kegolongan tertentu dan akan mendapatkan fasilitas kredit yang berbeda pula dari bank.

c. Perpose

Yaitu mengetahui tujuan nasabah dalam mengambil kredit termasuk jenis kredit yang diinginkan nasabah. Tujuan pengambilan kredit dapat bermacam-macam sesuai kebutuhan.

d. Prospect

Yaitu untuk menilai usaha nasabah di masa yang akan datang apakah menguntungkan atau tidak dengan kata lain mempunyai prospek atau sebaliknya. 


\section{e. Payment}

Merupakan ukuran bagaimana cara nasabah mengembalikan kredit yang telah diambil atau dari sumber mana saja dana untuk pengembalian kredit.

f. Profitabillity

Untuk menganalisis bagaimana kemampuan nasabah dalam mencari laba. Profitabillity diukur dari periode ke periode, Apakah akan tetap sama atau akan semakin meningkat, apalagi dengan tambahan kredit yang akan diperolehnya.

\section{g. Protection}

Tujuannya adalah bagaimana menjaga agar kredit yang diberikan mendapatkan jaminan perlindungan, sehingga kredit yang diberikan benarbenar aman.

Penilaian yang berdasarkan atas asas 3R terdiri dari:

a. Returns

Maksudnya penilaian atas hasil yang akan dicapai perusahaan calon debitur setelah memperoleh kredit.

b. Repayment

Memperhitungkan kemampuan, jadwal dan jangka waktu pembayaran kredit oleh calon debitur, tetapi perusahaan tetap berjalan.

c. Risk Bearing Ability

Memperhitungkan besarnya kemampuan perusahaan calon debitur untuk menghadapi resiko. Jika resiko perusahaan besar, maka kredit tidak akan diberikan, tetapi resiko perusahaan kecil, maka kredit dapat diberikan.

\section{ANALISIS dan PEMBAHASAN \\ Penyaluran kredit Pada PT. Bank Perkreditan Rakyat PMA Cabang Padang.}

Ketika bank memberikan pinjaman uang kepada nasabah,bank tentu saja mengharapkan uangnya kembali. Karenanya untuk memperkecil resiko. Untuk itu bank harus menjalankan prinsip $5 \mathrm{C}$ dalam pemberian kredit yaitu sebagai berikut:

\section{a. Character}

Adalah atas dasar kepercayaan yaitu adanya keyakinan dari pihak bank atau pemberi kredit bahwa peminjam memiliki moral, watak, ataupun sifat pribadi yang positif, kooperatif, dan juga penuh rasa tanggung jawab dalam kehidupan pribadi sebagai manusia, anggota masyarakat, atau pun dalam menjalankan kegiatan usahanya.

b. Capacity

Yaitu suatu penilaian kepada calon debitur mengenai kemampuan melunasi kewajiban-kewajibannya dari kegiatan usaha yang dilakukannya atau kegiatan usaha yang akan dilakukan atau dibiayai oleh kredit dari bank.

c. Capital

Yaitu jumlah dana atau modal yang dimiliki oleh calon debitur. 


\section{d. Collateral}

Yaitu barang-barang jaminan yang diserahkan yang diserahkan oleh peminjam atau debitur sebagai jaminan atas kredit yang diterimanya.

e. Condition Of Economy

Yaitu situasi dan kondisi sosial, politik, ekonomi, budaya, dan lainlain yang mempengaruhi keadaan perekonomian suatu negara pada suatu saat atau pada kurun waktu tertentu yang kemungkinannya akan dapat mempengaruhi kelancran usaha dari perusahaan yang memperoleh kredit.

Tabel

Perkembangan Total Kredit dan Non Performing Loan NPL PT. Bank Perkreditan Rakyat Prima Mulia Anugrah Cabang Padang Tahun 2015-2017

\begin{tabular}{|c|c|c|c|c|}
\hline Tahun & Total Kredit & $\begin{array}{c}\text { Perubahan } \\
\mathbf{\%}\end{array}$ & Jumlah NPL & $\begin{array}{c}\text { Perubahan } \\
\mathbf{\%}\end{array}$ \\
\hline $\mathbf{2 0 1 5}$ & - & - & - & - \\
\hline $\mathbf{2 0 1 6}$ & Rp. 7.370.507 & 0,0178 & Rp. 899.776 & $-1,996$ \\
\hline $\mathbf{2 0 1 7}$ & Rp. 7.238.598 & 0,0574 & Rp. 2.696.271 & 0,445 \\
\hline Total & Rp. 14.609.105 & \multicolumn{3}{|l}{} \\
\hline
\end{tabular}

Sumber : BPR PMA Cabang Padang, data diolah

Dari tabel 3.1 dapat diketahui total kredit maupun non performing loan (NPL) mengalami peningkatan dan penurunan dari tahun ketahun 20152016 mengalami peningkatan sebesar Rp. 7.370.507, perubahannya sebesar 0,0178\%, pada tahun 2016-2017 mengalami sedikit penurunan sebesar Rp. 7.238.598, sehingga terjadi perubahan sebesar $0,0574 \%$,

Pada tahun 2016 total kredit mengalami penurunan sebesar Rp.7.238.598.sedangkan NPL pada tahun 2016-2017 mengalami peningkatan perubahan sebesar $0,445 \%$. Jadi dari tabel 3.1 diatas dapat disimpulkan perubahan NPL yang paling besar yaitu ditahun 2016 dan 2017 dengan persentase $0,445 \%$.

\section{Kredit Bermasalah Pada PT. Bank Perkreditan Rakyat PMA Cabang Padang}

Kredit bermasalah adalah pemberian suatu fasilitas kredit mengandung resiko kemacetan.

(Ekonomika, Bisnis, \& Diponegoro, 2014) Kredit bermasalah atau Non Performing Loan (NPL), adalah terjadinya cidera janji dalam repayment kredit, sehingga terdapat tunggakan atau ada potensi kerugian yang terjadi pada usaha debitur sehingga memiliki kemungkinan timbulnya risiko di kemudian hari dalam arti luas bagi bank (Rivai, 2006). Penilaian kolektabilitas kredit digolongkan ke dalam 5 kelompok yaitu: lancar (pass), dalam perhatian khusus (special mention), kurang lancar (substandard), diragukan (doubtful) dan macet (loss). Apabila kredit dikaitkan dengan tingkat kolektabilitasnya, maka yang digolongkan kredit bermasalah adalah 
kredit yang memiliki kualitas kurang lancar, diragukan dan macet (Siamat, 2005).

Penyebab dari kesulitan-kesulitan keuangan perusahaan yang

mengakibatkan suatu kemacetan kredit dibagi kedalam dua kategori:

1. Faktor-faktor Intern (Managerial Factor)

Adalah faktor-faktor yang ada dalam diri perusahaan sendiri, dari segi managerial factor terjadinya kredit macet disebabkan oleh:

a. Kelemahan dalam kebijaksanaan pembelian dan penjualan

b. Tidak efektifnya kontrol atas biaya dan pengeluaran

c. Kebijaksanaan tentang kebijaksanaan piutang yang tidak efektif

d. Penempatan yang berlebihan pada aktiva tetap

e. Permodalan yang tidak cukup

2. Faktor-faktor Ekstern

Adalah faktor-faktor yang berasal dari luar perusahaan, faktorfaktor ekstern meliputi:

a. Bencana alam

Adalah sesuatu yang tidak kita inginkan misalnya kebakaran, gempa bumi, banjir dansebagainya.

b. Peperangan

Perang merupakan pengrusakan dan akibat dari peperangan ini merupakan bencan yang dibuat manusia, misalnya demonstrasi, penjarahan, pembakaran dan lain-lain.

c. Perubahan kondisi perekonomian

Misalnya peraturan pemerintah terhadap suatu jenis barang, keadan krisis misalnya demonstrasi, penjarahan, pembakaran dan lain-lain.

d. Perubahan teknologi

Semakin maju teknologi maka semakin efisien barang yang diproduksi sehingga perusahaan tidak menggunakan teknologi modern akan kalah bersaing.

\section{Pembahasan}

Non Performing Loan (NPL)

Tahun 2015

NPL $=$ Total Non Performing Loan $\times 100 \%$

Total Kredit

$=\underline{899.776} \times 100 \%$

7.370 .507

$=0,0122 \%$ 
Tahun 2016

NPL $=\underline{\text { Total Non Performing Loan }} \times 100 \%$

Total Kredit

$=\frac{2.696 .271}{7.238 .598} \times 100 \%$

$=0,3724 \%$

Tahun 2017

NPL = Total Non Performing Loan $\times 100 \%$

Total Kredit

$=\frac{1.493 .815}{6.822 .635} \times 100 \%$

$=0,2189 \%$

Tabel 3.2

Perhitungan Non Performing Loan (NPL)

PT. Bank Perkreditan Rakyat Prima Mulia Anugrah Cabang Padang

Tahun 2015-2017

\begin{tabular}{|c|c|c|c|}
\hline Tahun & Jumlah NPL & Jumlah Kredit & NPL \\
\hline 2015 & Rp. 899.776 & Rp. 7.370.507 & 0,0122 \\
\hline 2016 & Rp. 2.696.271 & Rp. 7.238.598 & 0,3724 \\
\hline 2017 & Rp. 1.493.815 & Rp. 6.822.635 & 0,2189 \\
\hline Total & Rp. 5.089.862 & RP. 21.431.740 & 0,6035 \\
\hline
\end{tabular}

Sumber: BPR PMA Cabang Padang, data diolah

Non Performing Loan (NPL) pada PT. Bank Perkreditan Rakyat Prima Mulia Anugrah Cabang Padang pada tahun 2015 nilainya cukup baik 0,0122\%, karena Non Performing Loan (NPL) yang baik adalah Non Performing Loan (NPL) yang memiliki nilai dibawah 5\%.

Non Performing Loan (NPL) pada PT. Bank Perkreditan Rakyat Prima Mulia Anugrah Cabang Padang pada tahun 2016 nilainya cukup baik 0,3724\%, karena Non Performing Loan (NPL) yang baik adalah Non Performing Loan (NPL) yang memiliki nilai dibawah 5\%.

Non Performing Loan (NPL) pada PT. Bank Perkreditan Rakyat Cabang Padang pada tahun 2017 nilainya cukup baik 0,2189\%, karena Non Performing Loan (NPL) yang baik adalah Non Performing Loan (NPL) yang memiliki nilai dibawah 5\%.

Dari analisa diatas dapat disimpulkan bahwa nilai NPL tahun 2015: 0,0122\%, tahun 2016: 0,3724\%, dan tahun 2017: 0,2189\%. Artinya kemampuan PT. Bank Perkreditan Rakyat Prima Mulia Anugrah Cabang Padang tahun 2015 memperoleh hasil yang cukup baik dari total kredit lancar yang disalurkan oleh bank kepada nasabah. 
Tabel 3.3

Evaluasi rata- rata industri

PT. Bank Pembangunan Daerah Sumatera Barat

Tahun 2014- 2016

\begin{tabular}{|c|c|c|c|c|c|c|c|}
\hline Rasio & $\begin{array}{c}\text { Rata-Rata } \\
\text { Industri }\end{array}$ & $\begin{array}{c}\text { Tahun } \\
\mathbf{2 0 1 5}\end{array}$ & Evaluasi & $\begin{array}{c}\text { Tahun } \\
\mathbf{2 0 1 6}\end{array}$ & Evaluasi & $\begin{array}{c}\text { Tahun } \\
\mathbf{2 0 1 7}\end{array}$ & Evaluasi \\
\hline NPL & $<5 \%$ & 0,0122 & Baik & 0,3724 & Baik & 0,2189 & Baik \\
\hline
\end{tabular}

Sumber: BPR PMA Cabang Padang, data diolah

Melalui ringkasan rasio keuangan PT. Bank Perkreditan Rakyat Prima Mulia Anugrah Cabang Padang, maka hasilnya dapat diuraikan sebagai berikut:

NPL ( Non Performing Loan ) PT. Bank Perkreditan Rakyat Prima Mulia Anugrah Cabang Padang tahun 2015, 2016, dan 2017 relatif baik dan sangat bagus karena bank tidak melampaui batas Kredit macet yang ditetapkan oleh bank indonesia, artinya bank mampu mengelola kreditnya dan pengembalian kembali kredit yang diberikan kepada nasabah.

\section{SIMPULAN}

Berdasarkan uraian yang telah dikemukakan, maka dapat ditarik kesimpulan sebagai berikut:

1. Bank Perkreditan Rakyat (BPR) Prima Mulia Anugrah merupakan bank yang bergerak memberikan pinjaman dalam bentuk kredit yang tujuannya adalah untuk membantu masyarakat yang kekurangan dana.

Penyaluran dana yang telah dihimpun kepda masyarakat yang membutuhkan dalam bentuk pinjaman Kredit, penggunaan dana bank dalam suatu bank pendapatan terbesar adalah pendapatan bunga dari penyaluran kredit. Sehingga hal ini menyebabkan bnyak bank berlombalomba meningkatkan penyaluran kreditnya dan akhirnya berdampak pada perkembangan modal.

2. Penyehatan kredit bermasalah yang dilakukan PT. Bank Perkreditan Rakyat PMA Cabang Padang dapat dilakukan dengan cara memberikan surat tunggakan dan peringatan kepada debitur, memberikan keringanan pembayaran bunga dan tunggakan pokok serta mendesak debitur untuk menjual agunan.

Penyebab utama dari kredit bermasalah bisa saja karena kesalahan dari pihak bank yang kurang tajam dalam menganalisis latar belakang calon nasabah, sehingga maksud dan tujuan serta sumber pembayaran kembali kredit yang diberikan tidak dapat diketahui secara jelas. Rendahnya tingkat pendidikan nasabah yang menerima kredit, serta kurang adanya komunikasi yang terbuka antara nasabah dengan bank juga dapat menyebabkan terjadinya kredit bermasalah, oleh karena itu 
diperlukan prinsip 5C, 7P, dan 3R dalam pengelolaan kredit bermasalah ini.

Tidak semua kredit bermasalah dapat ditangani dengan cara sama, beberapa diantaranya mungkin cukup dengan adanya koreksi disertai dengan monitoring yang lebih ketat, sementara yang lain harus ditempuh dengan cara penyehatan kredit dan yang paling buruk terpaksa dengan cara likuidasi untuk menutup kerugian bank.

\section{Saran}

Setelah memperhatikan masalah yang dihadapi oleh PT. Bank Perkreditan Rakyat PMA Cabang Padang maka penulis memberikan saransaran sebagai berikut:

1. Karyawan bank hendaknya dapat memberikan pelayanan semaksimal mungkin terhadap nasabah dalam meningkatkan promosi untuk menarik minat masyarakat melakukan hubungan dengan bank, baik berupa simpanan maupun kredit.

Untuk menambah kelancaran dalam pengelolaan kredit pada PT. Bank Perkreditan Rakyat PMA Cabang Padang hendaknya didukung oleh teknologi perbankan yang lebih mantap seperti perangkat komputer yang praktis dan efisien, serta teknologi perbankan yang baru.

2. Untuk mengantisipasi terjadinya kredit bermasalah sebaiknya bank meningkatkan monitoring dan pengawasan terhadap kredit yang diberikan baik mengenai manajemen maupun keadaan usaha debitur.

\section{UCAPAN TERIMAKASIH}

Dengan menyebut nama Allah SWT yang maha pengasih lagi maha penyayang, penulis ucapkan puji dan syukur atas kehadiran-Nya, yang telah melimpahkan rahmat, hidayahnya kepada penulis. Penulis ingin menyampaikan terima kasih yang tak terhingga atas bimbingan bapak Jhon Fernos SE,MM yang telah memberikan motivasi, masukan, maupun kritik dan dukungan secara moril maupun materil, serta untuk sahabat terbaik, terimakasih untuk semngat dan dukungannya yang sangat berguna untuk tugas akhir. Akhir kata penulis ucapkan terimakasih, semoga apa yang penulis tuangkan dalam karya kecil ini memberikan manfaat terutama bagi penulis sendiri. Amin ya Rabbal alamin

\section{DAFTAR PUSTAKA}

Alanshari, F., \& Marlius, D. (2018). Prosedur Pemberian Kredit KPR Pada PT. Bank Tabungan Negara (Persero) TBK Cabang Pembantu Bukittinggi. https://doi.org/10.31227/osf.io/rsfhc

Amelia, L., \& Marlius, D. (2018). Pengendalian Kredit Dalam Upaya Menciptakan Bank Yang Sehat Pada PT. Bank Pembangunan Daerah Sumatera Barat Cabang Utama Padang. https://doi.org/10.31227/osf.io/kpc64 
Iqbal, M., \& Marlius, D. (2017). Pengaruh Jumlah Taksiran Dan Uang Pinjaman Terhadap Laba Bersih Pada PT. Pegadaian (UPC) Gurun Laweh. https://doi.org/10.31227/osf.io/uch4a

Afriyeni. A, Fernos. J. (2018). Analisis Faktor-Faktor Penentu Kinerja Profitabilitas Bank Perkreditan Rakyat (BPR) Konvensional Di Sumatera Barat. Jurnal Benefita. ejournal.kopertis10.or.id. http://doi.org/10.22216/jbe.v3i3.3623

Shanjaya, A. R., \& Marlius, D. (2017). Peranan Laporan Keuangan Dalam Kebijaksanaan Pemberian Kredit Kepada Calon Nasabah Pada PT. BPR Batang Kapas. https://doi.org/10.31227/osf.io/uxmg6 